\title{
Examining Relationship between Teachers' Self-efficacy and Job Satisfaction
}

\author{
Muhammet Emin Türkoğlü ${ }^{1, *}$, Ramazan Cansoy $^{2}$, Hanifi Parlar ${ }^{3}$ \\ ${ }^{1}$ Faculty of Education, Afyon Kocatepe University, Ahmet Necdet Sezer Campus, Turkey \\ ${ }^{2}$ Faculty of Letter, Karabuk University, Turkey \\ ${ }^{3}$ Faculty of Humanities and Social Sciences, Istanbul Commerce University, Sutluce Campus, Turkey \\ *Corresponding Author: eminturkoglu@gmail.com
}

Copyright $\mathrm{O} 2017$ by authors, all rights reserved. Authors agree that this article remains permanently open access under the terms of the Creative Commons Attribution License 4.0 International License

\begin{abstract}
Teaching in the 21 st century poses many challenges for teachers, and thus, they need to take on more roles in their schools to meet the expectations of students, parents and the school community. In this regard, this study examined the relationship between teachers' self-efficacy beliefs and their job satisfaction. Participants of the study were 489 elementary, middle and high school teachers in the district of Beyoğlu, İstanbul. 295 (61\%) of the participants were female and $194(39 \%)$ were male. The average age of the participants was 34 . Their teaching experience varied between 1-29 years. The results revealed a significant positive relationship between teacher self-efficacy and job satisfaction, and teacher self-efficacy was found to be a significant predictor of job satisfaction.
\end{abstract}

Keywords Teacher Self-efficacy, Job Satisfaction, Teacher

\section{Introduction}

Teaching in the 21 st century poses a number of challenges for teachers $[25,38,55]$. Due to these challenges, teachers need to take on more roles in their schools to address the expectations of students, parents and the community. These expectations have brought about the need for lifelong learning, with competencies such as research, critical thinking, problem-solving, teamwork, and the use of information and communication technologies, which has considerably changed responsibilities of teachers. In addition, teachers' competence in certain fields and their satisfaction has become a must for organizational performance and productivity [11].

Job satisfaction is of great importance for the teaching profession since it is the teachers to teach students. Teachers are influenced by individual, and contextual factors such as school culture. Therefore, they need to focus on what individual or contextual factors could be changed in order to increase the job satisfaction [59]. Improving relations with the school community can be useful in this sense [43]. Alternatively, self-efficacy can also help enhance job satisfaction. Self-efficacy is one's belief about his/her capabilities. These capabilities are highly related to the perception of performance that could affect the results of events [8]. Teachers build up self-efficacy through achieving challenging tasks. This brings about motivation which is a unique remedy to overcome the feeling of failure [6].

A review of the relevant literature shows that educational outcomes correlate positively with teacher job satisfaction $[34,21]$. However, teachers feel overwhelmed by the challenges of the school context. As a developing country Turkey has been struggling for student achievement especially for the last decade. Great effort is put into education both economically and politically. However, international data like PISA results indicate that Turkey's improvement is either static or very limited [44]. In this regard, teachers are in the key position in raising individuals for the future. For this reason, more studies should be conducted on self-efficacy and job satisfaction of teachers. In this context, this study is thought to have a contribution to our understanding of the relationship between self-efficacy and job satisfaction.

\subsection{Teacher Self-efficacy}

Self-efficacy is an individual's belief about his/her capability to manage responsibilities [7]. More specifically, teacher self-efficacy is about the desired learning objectives of a teacher to improve his/her students' learning [39]. Better educational outcomes depend on the level of teacher self-efficacy. Low levels of teacher self-efficacy may inhibit the level of achievement at school [10, 27, 49]. There are certain personal and environmental factors in developing self-efficacy. These include believing in one's capacity to accomplish a task, modeling successful people and getting support of others [6].

Self-efficacy of teachers is also related to teachers' content 
knowledge in their classes [32], "students' academic adjustment, patterns of teacher behaviour and practices related to classroom quality, and factors underlying teachers' psychological well-being, including personal accomplishment, job satisfaction, and commitment" [61], and coping with behavioural problems [23]. Moreover, teachers need motivation in their workplaces. A teacher's self-efficacy beliefs improve his/her motivation $[9,49,50]$ which may have a significant contribution to school society [16].

Teacher self-efficacy has three dimensions, which are efficacy for student engagement, efficacy for instructional strategies, and efficacy for classroom management [49]. A teacher with a high level of self-efficacy is successful in student engagement, instructional strategies and classroom management by letting students participate in the lesson, improving teaching practices and carrying out a good orchestration of the learning environment.

\subsection{Teacher Job Satisfaction}

Working environment is a place where people spend most of their life. Job satisfaction arises from the attitudes that employees have developed towards their job. Emotions are related to job satisfaction that is a satisfactory or unsatisfactory emotional response to the working environment and the job [4]. A teacher may feel content in his profession for many reasons, and thus, there are different understandings of the concept of teacher job satisfaction. Teachers are influenced by individual, and contextual factors such as school culture [59]. Teacher demographics like age, gender and teaching experience may enhance our understanding of teacher job satisfaction [24].

Teacher job satisfaction is about "measuring teachers' satisfaction with different circumstances" [43]. Teachers get their job satisfaction from their relations with students [21, 41]. A teacher's job satisfaction may also be influenced by his/her students' success [48]. Moreover, performance rewards play an important role on job satisfaction [18]. However, in many countries, teachers' job satisfaction is "at risk due to new responsibilities and to the scarcity of external rewards" [15]. These might be caused by rapid changes and big challenges of educational environments, society and expectations of parents, students and administrators. Besides, educational policies and new laws regarding teachers may also have an influence on teacher job satisfaction.

Job satisfaction can be explained as a consequence of efficient work. Job satisfaction of administrators has six dimensions: nature of work, salary, development and promotion possibilities, working conditions, interpersonal relations, organizational environment [5]. These dimensions were used in different studies in order to understand the nature of job satisfaction of administrators and teachers [1, $26,58]$. In this study, these dimensions were adapted to have a better understanding of the nature of teacher job satisfaction.

\subsection{Turkish Education System}

Turkish education is governed by a national a state-supervised system. Compulsory education lasts 12 years between the ages 6 to 18. Education is financed by the state and free of charge in public schools. Students can go to university after graduating high schools. For formal education at universities, students enter a national examination after which high school graduates are assigned to university according to their scores in the given tests [46]. Teacher training in Turkey is carried out in the Education Faculties in universities. By 2016, there were 183 universities in Turkey [51]. Pre-service teachers in these faculties graduate with 4 years of education in different fields [57]. In order to become a teacher, pre-service teachers enter the PPSE (Public Personnel Selection Exam) and compete to enter the staffs within certain quotas [2].

There are 89 teacher education faculties in Turkey. Almost 50,000 pre-service teachers were enrolled for teaching programs in 2014-2015 academic year [60]. After graduating their faculties pre-service teachers enter a national exam to be appointed. Thousands of pre-service teachers, who have different scores from PPSE (Public Personnel Selection Exam) exam, are waiting to be appointed to teaching positions. However, the number of unemployed pre-service teachers has been increasing. On the other hand, students from other faculties were given a right to become a teacher which has increased the number of unemployed teachers. In 2010, in a regulation organized by HEI (Higher Education Institution) science and literature faculties' students were also given a right to complete pedagogical formation education to work as teachers [35].

According to the formal education statistics covering pre-primary, primary and secondary education institutions of 2015-2016 education and training period, 17,588,958 students benefited from formal education. The number of teachers working in formal education institutions was 993,794 in the same period. In Turkey, $45.1 \%$ of the teachers are male and 54.95 are women [53].The retirement age in Turkey is 58 for women teachers and 60 for male teachers as of today. In general, teachers do not prefer to retire when they have completed their term. Teachers see their job as a life-long profession. The salaries of teachers in Turkey are about 23 thousand dollars at all levels. The OECD average, on the other hand, ranges from 28 thousand to 31 thousand dollars. Teacher salaries in Turkey are below most OECD countries. Teachers in Turkey work on the OECD average. The working hours of teachers in Turkey are around 1800 hours and above the OECD average (1,678 hours). Average class size in Turkey is higher than many OECD countries. Similarly, the number of students per teacher directly affects teachers' working lives and job satisfaction [52].

\subsection{Relationship between Teacher Job Satisfaction and Teacher Self-efficacy}

Research on teachers shows that self-efficacy is positively 
related to job satisfaction $[37,35,42]$ and teacher self-efficacy has a considerable effect on job satisfaction [54, 59]. Teachers with high levels of self-efficacy have strong communication in the workplace which leads to job satisfaction [15]. In this context, the following research questions were addressed in the present study.

1. What are teachers' perceptions of their job satisfaction and teacher self-efficacy?

2. Is there a significant relationship between teachers' job satisfaction and teacher self-efficacy?

3. Is teacher self-efficacy a significant predictor of teacher job satisfaction based on the teachers' perceptions?

\section{Method}

In this section, the research model, participants, data collection tools, procedure and data analysis of the study were explained.

\subsection{Research Model}

This study was designed in relational model to examine the relationship between elementary, middle and high school teachers' teacher self-efficacy and job satisfaction. The sample consists of 489 teachers working in Beyoğlu district of Istanbul who were chosen through the simple random sampling method. $295(61 \%)$ of the participants were female and $194(39 \%)$ were male. The average age of the participants was 34 , and their teaching experience ranged between 1-29 years.

\subsection{Data Collection Tools}

\subsubsection{Administrator's Job Satisfaction Scale}

This scale was developed by Balc1 [5] in order to measure the job satisfaction of school administrators. However, different arrangements were made so that it could be applied to teachers later in different studies $[11,47]$. The scale reveals job satisfaction levels of teachers, and consists of 6 dimensions and 27 items. A 5-point rating scale is used with options ranging from "(1) Strongly disagree" to "(5) Strongly agree". Dimensions of the scale are job and its quality, salary, opportunities for development and promotion, working conditions, interpersonal relationships and organizational setting. Cronbach's Alpha coefficients calculated in [5] ranged from 0.76 to 0.95 . This scale was used in different studies and yielded reliability values of 0.70 and above for all subscales and the whole scale [11,20]. Scale dimensions and sample items are as follows: Job and its quality "I have a job that is not routinized and boring", salary "I have no difficulty in supporting for myself and my family with my salary", opportunities for development and promotion "This school has a fair promotion policy", working conditions "Recreation and entertainment facilities are sufficient", interpersonal relationships "We are building a successful team with our assistants", organizational environment "Communication in our school is always open".

Confirmatory factor analysis (CFA) was performed to determine whether 27 items and the six-dimensional structure in the job satisfaction scale were consistent with the data of this study. The factor structure of the scale was confirmed. In this context, it can be said that the model showed an acceptable fit with the data according to the fit indices, $\left(\mathrm{X}^{2}=556.46 ; \mathrm{p}<0.05 ; \mathrm{sd}=305 ; \mathrm{X}^{2} / \mathrm{sd}=1.82\right.$; RMSEA $=0.045$; CFI $=0.95$; GFI $=0.91$ ). The factor loadings of the items in the scale ranged from 0.54 to 0.82

The Cronbach's Alpha coefficients calculated to test the reliability of the scale in the present study were as follows: 0.87 for job and its quality, 0.66 for salary, 0.82 for opportunities for development and promotion, 0.61 for interpersonal relationships, 0.85 for working conditions, and 0.92 for organizational setting. The Cronbach's Alpha coefficient, calculated for the reliability of the entire scale, was found to be 0.92 .

\subsubsection{Teacher Self-efficacy Scale}

The scale was developed by [40], and adapted to Turkish by [19]. The scale consists of 24 items and three dimensions. A nine-point grading scale is used with options ranging from "(1) Insufficient" to "(9) Very good". Low scores in the scale indicate a low level of teacher self-efficacy belief, whereas high scores show a high level of teacher self-efficacy belief. The dimensions of the scale are as follows: self-efficacy for student participation, self-efficacy for instructional strategies, and self-efficacy for classroom management. Each dimension consists of eight items. [19] reported that Cronbach's Alpha coefficients for reliability in their study were 0.82 for self-efficacy for students, .86 for self-efficacy for instructional strategies, 0.84 for self-efficacy for classroom management and 0.93 for the whole scale. Sample items include "How much can you do to get through the most difficult students?"; "How well can you respond to difficult questions from your students" and "How well can you respond to defiant students?".

Confirmatory factor analysis (DFA) was conducted to determine if 24 items and the three-dimensional structure in the teacher self-efficacy scale were consistent with the data of this study. The factor structure of the scale was confirmed. In this context, it can be said that the model showed an acceptable fit with the data according to the fit indices. The factor loadings of the items in the scale varied between 0.58 and 0.74, $\left(\mathrm{X}^{2}=998.47, \mathrm{p}<.05, \mathrm{sd}=237 ; \mathrm{X}^{2} / \mathrm{sd}=4.21\right.$; RMSEA $=0.081$; CFI $=0.88$; GFI $=0.84$ ).

The Cronbach's Alpha coefficients calculated in the present study were as follows: 0.86 for self-efficacy for student engagement, 0.87 for efficacy for instructional strategies, 0.90 for efficacy for classroom management, and 0.95 for the whole scale. The reliability values for the scale were found to be 0.70 and above $[13,29]$. 


\subsection{Analysis of Data}

SPSS 17 program was used in the analysis of the data. Missing data and outliers were examined for multiple changes for the regression analysis. Perceptions of the teachers' job satisfaction and their perceptions of teacher self-efficacy were calculated. The Pearson Moments Multiplication Correlation Coefficient and the 'enter' method in multiple linear regression were employed to reveal the relationships between the variables in the study. This analysis was used to determine whether teacher self-efficacy predicted teacher job satisfaction. As a result of the analysis, it was seen that no tolerance values close to 0 was found. At the same time, VIF values were found to be lower than 10. The relationship between the predictor variables was $(r=0.78)$ and below. No condition index greater than 30 was found. If the tolerance value is less than 0.20 , the VIF value is greater than 10 , the CI value is higher than 30 , and the correlations between the independent variables are 0.80 and above, this may be a sign for multi-connectivity [14]. Therefore, it was decided that there was no multicollinearity problem according to these results. The skewness and kurtosis values for the data were found to be between 0.49 and 0.52 . If these values are between +1 and -1 , it indicates closeness to normal distribution. Moreover, it was also assumed that the data were normally distributed by mode, median, arithmetic mean values, normal Q-Q graph, skewness and kurtosis values.

The fit indices used when confirming factor analysis is done according to [22]. The coefficient obtained from AGFI is $0.85[3,17]$ or $0.90[30,40]$ can be accepted. Values from RMSEA of less than or equal to 10 are sufficient for compliance. The good fit of the ratio of $\chi^{2} / \mathrm{df}$ is between 2-5, while the values less than 2 are perfect fit [28].

\section{Findings and Interpretation}

\subsection{Relationships between Variables}

Table 1 shows the arithmetic mean, standard deviations, and the correlation coefficients between the dependent and independent variables of the study.

Dimensions of the Job Satisfaction scale are job and its quality, salary, opportunities for development and promotion, working conditions, interpersonal relationships and organizational setting. Dimensions of the Self-efficacy scale are student engagement, instructional strategies and classroom management.

According to the arithmetic means of job satisfaction in this study, it can be stated that the teachers were more satisfied with the job and its quality, interpersonal relationships, and organizational setting, which were followed by salary, opportunities for development and promotion and working conditions (see Table 1).

The teachers' beliefs about instructional strategies were found to be at the highest level among the self-efficacy dimensions, while their beliefs of efficacy for student participation was at the lowest level. According to this finding, it can be said that the teachers had a sufficient level of self-efficacy to encourage students to participate in classes (see Table 1).

As can be seen in Table 1, the results of the correlation analysis showed that efficacy for student engagement, efficacy for instructional strategies and efficacy for classroom management correlated positively with job and its quality, opportunities for development and promotion, working conditions, interpersonal relationships, and organizational setting. However, there was no significant relationship between salary and teacher self-efficacy.

Table 1. Relationships between teacher self-efficacy and job satisfaction

\begin{tabular}{|c|c|c|c|c|c|c|c|c|c|c|c|c|}
\hline Variables & $\bar{X}$ & $\mathrm{~S}$ & 1 & 2 & 3 & 4 & 5 & 6 & 7 & 8 & 9 & 10 \\
\hline \multicolumn{13}{|l|}{ Job Satisfaction } \\
\hline 1. Job and its quality & 3.05 & .99 & 1 & $.284^{* *}$ & $.561^{* *}$ & $.362^{* *}$ & $.418^{* *}$ & $.522^{* *}$ & $.743^{* *}$ & $.305^{* *}$ & $.230^{* *}$ & $.234^{* *}$ \\
\hline 2. Salary & 1.99 & .89 & & 1 & $.393^{* *}$ & $.357^{* *}$ & $.155^{* *}$ & $.227^{* *}$ & $.529^{* *}$ & 0.03 & 0.02 & -0.015 \\
\hline $\begin{array}{l}\text { 3. Opportunities for } \\
\text { Development and } \\
\text { promotion }\end{array}$ & 2.50 & .98 & & & 1 & $.608^{* *}$ & $.451^{* *}$ & $.592^{* *}$ & $.830^{* *}$ & $.238^{* *}$ & $.179^{* *}$ & $.127^{* *}$ \\
\hline 4. Working conditions & 2.40 & .98 & & & & 1 & $.418^{* *}$ & $.458^{* *}$ & $.745^{* *}$ & $.175^{* *}$ & $.130^{* *}$ & $.131^{* *}$ \\
\hline $\begin{array}{l}\text { 5. Interpersonal } \\
\text { relationships }\end{array}$ & 3.74 & .79 & & & & & 1 & $.654^{* *}$ & $.671^{* *}$ & $.267^{* *}$ & $.242^{* *}$ & $.257^{* *}$ \\
\hline $\begin{array}{l}\text { 6. Organizational } \\
\text { setting }\end{array}$ & 3.54 & .96 & & & & & & 1 & $.814^{* *}$ & $.265^{* *}$ & $.204^{* *}$ & $.249^{* *}$ \\
\hline $\begin{array}{l}\text { 7. Job satisfaction } \\
\text { (Whole Scale) }\end{array}$ & 2.87 & .69 & & & & & & & 1 & $.298^{* *}$ & $.229^{* *}$ & $.228^{* *}$ \\
\hline \multicolumn{13}{|l|}{ Self-efficacy } \\
\hline 8. Student engagement & 6.54 & 1.04 & & & & & & & & 1 & $.780^{* *}$ & $.762^{* *}$ \\
\hline $\begin{array}{l}\text { 9. Instructional } \\
\text { strategies }\end{array}$ & 7.02 & 1.02 & & & & & & & & & 1 & $.748^{* *}$ \\
\hline $\begin{array}{l}\text { 10. Classroom } \\
\text { management }\end{array}$ & 6.91 & 1.14 & & & & & & & & & & 1 \\
\hline$* * p<.05$ & & & & & & & & & & & & \\
\hline
\end{tabular}




\subsection{Predicting Teacher Job Satisfaction}

The results of multiple linear regression analysis for the predictive power of teacher self-efficacy over teacher job satisfaction are given in Table 2.

The results of the regression analysis to determine whether the teacher self-efficacy dimensions predict job satisfaction are presented in Table 2. According to the results, efficacy for student participation positively predicted job and its quality, opportunities for development and promotion, working conditions, interpersonal relationships, and organizational setting as the only common predictor.

The teachers' satisfaction with the opportunities for development and promotion was predicted positively and significantly by the self-efficacy dimensions of student participation and classroom management. The dimensions of teacher self-efficacy together accounted for $9 \%$ of the variance in satisfaction with job and its quality, $6 \%$ in satisfaction with the opportunities for development and promotion, $3 \%$ of variance in satisfaction with working conditions, and $8 \%$ of the variance in satisfaction with organizational development. All dimensions of teacher self-efficacy together explained $9 \%$ of the variance in teacher job satisfaction. Thus, self-efficacy beliefs can be said to be an important variable in maintaining job satisfaction.

Satisfaction with the opportunities for development and promotion is predicted positively and significantly by efficacy for student engagement and efficacy for classroom management sub-dimensions. Teacher self-efficacy dimensions together accounted for $9 \%$ of the variance of satisfaction for job and its quality, $6 \%$ of satisfaction for development and promotion opportunities, $3 \%$ of the variance for satisfaction of working conditions, $8 \%$ of the variance of satisfaction for organizational environment. The variance explained by self-efficacy sub-dimensions on total job satisfaction is $9 \%$.

Table 2. Results of multiple regression analysis on teacher self-efficacy and job satisfaction

\begin{tabular}{|c|c|c|c|c|c|c|c|c|c|}
\hline Variables & & B & SD & $\beta$ & $\mathbf{t}$ & $\mathbf{p}$ & Two-tailed & Partial & $\mathbf{R}^{2}$ \\
\hline \multirow{4}{*}{ 1. Job and its quality } & Constant & 1.18 & .31 & & 3.82 & .00 & & & \\
\hline & Student engagement & .30 & .07 & .32 & 4.15 & .00 & .31 & .19 & \\
\hline & Instructional Strategies & -.03 & .07 & -.03 & -.36 & .72 & .23 & -.02 & .09 \\
\hline & Classroom management & .01 & .06 & .01 & .17 & .87 & .23 & .01 & \\
\hline \multirow{4}{*}{ 2. Salary } & Constant & 1.88 & .29 & & 6.50 & .00 & & & \\
\hline & Student engagement & .08 & .07 & .10 & 1.22 & .22 & .03 & .06 & \\
\hline & Instructional strategies & .02 & .07 & .03 & .32 & .75 & .02 & .01 & .01 \\
\hline & Classroom management & -.09 & .06 & -.11 & -1.44 & .15 & -.02 & -.07 & \\
\hline \multirow{4}{*}{$\begin{array}{l}\text { 3. Opportunities for development } \\
\text { and promotion }\end{array}$} & Constant & 1.13 & .31 & & 3.64 & .00 & & & \\
\hline & Student engagement & .30 & .07 & .32 & 4.08 & .00 & .24 & .18 & \\
\hline & Instructional strategies & .04 & .07 & .04 & .52 & .60 & .18 & .02 & .06 \\
\hline & Classroom management & -.13 & .06 & -.14 & -1.98 & .049 & .13 & -.09 & \\
\hline \multirow{4}{*}{ 4. Working conditions } & Constant & 1.35 & .31 & & 4.29 & .00 & & & \\
\hline & Student engagement & .18 & .07 & .19 & 2.36 & .02 & .17 & .11 & \\
\hline & Instructional strategies & -.01 & .07 & -.02 & -.20 & .84 & .13 & -.01 & .03 \\
\hline & Classroom management & .00 & .06 & .00 & .00 & 1.00 & .13 & .00 & \\
\hline \multirow{4}{*}{ 5. Interpersonal relationships } & Constant & 2.23 & .25 & & 8.98 & .00 & & & \\
\hline & Student participation & .11 & .06 & .15 & 1.91 & .06 & .27 & .09 & \\
\hline & Instructional strategies & .03 & .06 & .04 & .58 & .56 & .24 & .03 & .08 \\
\hline & Classroom management & .08 & .05 & .11 & 1.54 & .12 & .26 & .07 & \\
\hline \multirow{4}{*}{ 6. Organizational setting } & Constant & 1.89 & .30 & & 6.32 & .00 & & & \\
\hline & Student participation & .19 & .07 & .21 & 2.70 & .01 & .27 & .12 & \\
\hline & Instructional strategies & -.06 & .07 & -.06 & -.78 & .44 & .20 & -.04 & .08 \\
\hline & Classroom management & .11 & .06 & .13 & 1.84 & .07 & .25 & .08 & \\
\hline \multirow{4}{*}{ 7. Job Satisfaction (Whole Scale) } & Constant & 1.58 & .22 & & 7.33 & .00 & & & \\
\hline & Student participation & .20 & .05 & .30 & 3.93 & .00 & .30 & .18 & \\
\hline & Instructional strategies & -.01 & .05 & -.01 & -.15 & .88 & .23 & -.01 & .09 \\
\hline & Classroom management & .00 & .04 & .01 & .10 & .92 & .23 & .00 & \\
\hline
\end{tabular}

$\mathrm{P}<.05$ 


\section{Discussion, Conclusion and Suggestions}

The present study examined the relationships between the variables of teacher self-efficacy and teacher job satisfaction. According to the results, self-efficacy correlated positively with teacher job satisfaction, which shows that when teachers' perceptions of self-efficacy increase, their job satisfaction will also increase. In this regard, there are some studies that report similar results. Teachers with high self-efficacy are observed to achieve more educational outcomes than those with lower levels [10, 27, 49].

With respect to the first question of the study, which was "What are teachers' perceptions of their job satisfaction and teacher self-efficacy?", the teachers were found to be more satisfied with the job and its quality, interpersonal relationships, and organizational setting. However, salary, opportunities for development and promotion and working conditions were not among the aspects which they were satisfied with at a high level. Similar results are reported in different studies. According to [31] "income" dimension affect job satisfaction of teachers the least. The same result has been reached in many researches that examine the salary relation of job satisfaction [33, 36, 37]. Improving relations with the school community can increase job satisfaction [43]. Moreover, job satisfaction is a response to the working environment. An organization's setting is also important for developing job satisfaction to a high level [4]. On the other hand, the teachers' beliefs about instructional strategies were found to be at the highest level among self-efficacy dimensions in the present study, whereas efficacy for student participation was found to be lower than other dimensions.

As for the second research question, which was "Is there a significant relationship between teachers' job satisfaction and teacher self-efficacy?", the results of the correlation analysis showed that efficacy for student engagement, efficacy for instructional strategies and efficacy for classroom management were positively related to job and its quality, opportunities for development and promotion, working conditions, interpersonal relationships, and organizational setting. Similarly, research on teachers shows that self-efficacy is positively related to job satisfaction [42, 44, 54]. However, there was no significant relationship between salary and teacher self-efficacy $[33,36,37]$.

Regarding the third research question, which was "Is teacher self-efficacy a significant predictor of teacher job satisfaction based on the teachers' perceptions?", multiple regression analysis was conducted to reveal the predictive power of self-efficacy over job satisfaction. The results showed a positive relationship between teacher self-efficacy and job satisfaction. The regression analysis demonstrated that self-efficacy towards student participation was the only common predictor of the job satisfaction dimensions including job and its quality, opportunities for development and promotion, working conditions, interpersonal relationships and organizational setting, which points to the importance of student participation for teachers, and is supported by the results of different studies. Teachers with high levels of self-efficacy are reported to have strong communication in the workplace which enhances job satisfaction [15]. According to a similar result, the inter-employee relationship dimension can be explained as one of the most important factors affecting job satisfaction factor. This result shows that teachers communicate well with their friends and they like to decide together. [31].

To summarize all these results, there was a significant positive relationship between teacher self-efficacy and job satisfaction, and teacher self-efficacy was a significant predictor of job satisfaction. The results of the study reveal that self-sufficiency is important in terms of improving job and its quality, opportunities for development and promotion, working conditions, interpersonal relationships and organizational setting. Prioritizing school-based practices is of significance. For this purpose, projects can be implemented with the cooperation of universities and schools in order to improve the self-efficacy perceptions of teachers. Seminars regarding self-efficacy and job satisfaction can be beneficial for teachers. Besides, teachers who are successful in teaching can guide new teachers. It is emphasized that the programs of teacher training institutions should be regulated in a self-efficacy manner, emphasizing that self-efficacy belief decreases the negative thoughts of the individual and increases motivation and performance [12]. According to [45], for the Turkish education system the concept of self-efficacy is very important for teachers. Literature puts forth information which supports that high self-efficacy teachers' contributions to the education system will be high. For this reason, it is considered important to develop teachers' self-efficacy at education faculties. This study, which examined the relationship between self-efficacy and job satisfaction, was conducted on elementary, middle and high school teachers. There is a need for further research on teacher candidates who have not yet started their profession.

The present study has certain limitations. It was carried out only in single district (i.e. Beyoğlu) of Istanbul. Although the study reports significant findings, other schools in other parts of the city may also provide valuable data. Future studies can be extended to other school contexts.

\section{REFERENCES}

[1] Akın, A. G. U., \& Koçak, R. (2007). Öğretmenlerin sınıf yönetimi becerileri ile iş doyumları arasındaki ilişki. Kuram ve Uygulamada Ĕ̈itim Yönetimi, 51(51), 353-370.

[2] Aksoy, E. (2017). Turkish student teachers' attitudes toward teaching in university-based and alternative certification programs in Turkey. Asia Pacific Education Review, 1-12.

[3] Anderson, J. C., \& Gerbing, D. (1984). The effect of sampling error on convergence, improper solutions, and goodness-of-fit 
indices for maximum likelihood confirmatory factor analysis. Psychometrika, 49, 155-173.

[4] Avşaroğlu, S., Deniz, M. E., \& Kahraman, A. (2005). Teknik öğretmenlerde yaşam doyumu iş doyumu ve mesleki tükenmişlik düzeylerinin incelenmesi. Selçuk Üniversitesi Sosyal Bilimler Enstitüsü Dergisi, (14), 115-129.

[5] Balc1, A. (1985). Eğitim Yöneticisinin $\dot{I}_{S ̧}$ Doyumu. Yayımlanmamış Doktora Tezi. Ankara Üniversitesi, Ankara.

[6] Bandura, A. (1977) Self-efficacy: toward a unifying theory of behavioral change, Psychological Review, 84(2), 191-215. http://dx.doi.org/10.1037/0033-295X.84.2.191

[7] Bandura, A. (1986). Social foundations of thought and action: A social cognitive theory. Prentice-Hall, Inc.

[8] Bandura, A. (1994) Self-efficacy, in V.S. Ramachandran (Ed.) Encyclopedia of Human Behavior, vol. 4, pp. 71-81.New York: Academic Press.

[9] Bandura, A. (1997). Self-efficacy: The exercise of control. New York: Freeman.

[10] Battersby, S. L., \& Cave, A. (2014). Preservice classroom teachers' preconceived attitudes, confidence, beliefs, and self-efficacy toward integrating music in the elementary curriculum. Update: Applications of Research in Music Education, 32(2), 52-59.

[11] Buluç, B., \& Demir, S. (2015). İlk ve Ortaokul Öğretmenlerinin Öz-Yeterlik Algıları ile İş Doyumları Arasındaki İlişki. Ahi Evran Üniversitesi Kırşehir Ĕgitim Fakültesi Dergisi (KEFAD), 16(1), 289-308.

[12] Bussey, K., \& Bandura, A. (1999). Social cognitive theory of gender development and differentiation. Psychological Review, 106, 676-713.

[13] Bümen, N. T.; Özaydın, T.E. (2013). Adaylıktan Göreve Öğretmen Özyeterliği ve Öğretmenlik Mesleğine Yönelik Tutumlardaki Değişimler. Eğitim ve Bilim, 38 (169), 1300-1337.

[14] Büyüköztürk, Ş. (2010). Sosyal bilimler için veri analizi el kitabı. Ankara: Pegem Akademi.

[15] Caprara, G. V., Barbaranelli, C., Steca, P., \& Malone, P. S. (2006). Teachers' self-efficacy beliefs as determinants of job satisfaction and students' academic achievement: A study at the school level. Journal of school psychology, 44(6), 473-490.

[16] Coladarci, T. (1992). Teachers' sense of efficacy and commitment to teaching. The Journal of experimental education, 60(4), 323-337.

[17] Cole, D. A. (1987). Utility of confirmatory factor analysis in test validation research. Journal of Consulting and Clinical Psychology, 55, 1019-1031.

[18] Conley, S., \& Levinson, R. (1993). Teacher work redesign and job satisfaction. Educational Administration Quarterly, 29(4), 453-478.

[19] Çapa, Y., Çakıroğlu, J. ve Sarıkaya, H. (2005). Öğretmenlik öz-yeterlik ölçeğinin Türkçe uyarlamasının geçerlik ve güvenirlik çalışması. Eğitim ve Bilim, 30(137), 74-81.

[20] Çelebi, C. (2012). İlköğretim okullarında görev yapan okul müdürlerinin okulda gösterdikleri liderlik stilleri ile öğretmenlerin iş doyumu arasındaki ilişki (Yayımlanmamış yüksek lisanz tezi). Gazi Üniversitesi, Ankara.

[21] Dinham, S. (1995). Time to focus on teacher satisfaction (Shorter version of a paper, Enhancing the Quality of Teacher Satisfaction, presented to the Australian College of Education. Conference (1994: Launceston).). Unicorn (Carlton, Vic), 21(3), 64

[22] Doll, W.J., Xia, W. \& Torkzadeh, G.A. (1994). A confirmatory factor analysis of the end-user computing satisfaction instrument. Management Information Systems Quarterly, 18, 453-61.

[23] Egyed, C. J., \& Short, R. J. (2006). Teacher self-efficacy, burnout, experience and decision to refer a disruptive student. School Psychology International, 27(4), 462-474.

[24] Fairchild, S., Tobias, R., Corcoran, S., Djukic, M., Kovner, C., \& Noguera, P. (2012). White and Black teachers' job satisfaction: Does relational demography matter? Urban Education, 47(1), 170-197.

[25] Firestone, W. A. (2014). Teacher evaluation policy and conflicting theories of motivation. Educational Researcher, 0013189 X14521864.

[26] Gençtürk, A., \& Memiş, A. (2010). An investigation of primary school teachers' teacher efficacy and job satisfaction in terms of demographic factors. Elementary Education Online, 9(3), 1037-1054.

[27] Henson, R. K. (2001). Teacher Self-Efficacy: Substantive Implications and Measurement Dilemmas.

[28] Jöreskog, K., \& Sörbom, D. (2001). LISREL 8.51. Mooresville: Scientific Software.

[29] Karabacak, M. S. (2014). Ankara ili genel liselerinde görev yapan ögretmenlerin özerklik algıları ile öz-yeterlik algıları arasındaki ilişki (Yayımlanmamış yüksek lisans tezi). Ankara Üniversitesi, Ankara.

[30] Kline, R. B. (2005). Principle and practice of structural equation modeling. New York, NY: Guilford.

[31] Kuruüzüm, A., \& Çelik, N. (2005). İkinci mertebeden faktör modeli ile öğretmen iş doyumunu belirleyen faktörlerin analizi. Hacettepe Üniversitesi Eğitim Fakültesi Dergisi, 29(29).

[32] Marri, A. R., Ahn, M., Fletcher, J., Heng, T. T., \& Hatch, T. (2012). Self-Efficacy of US High School Teachers Teaching the Federal Budget, National Debt and Budget Deficit: a mixed-methods case study. Citizenship, Social and Economics Education, 11(2), 105-120.

[33] Mete, C. (2006). İlköğretim okullarında çalışan öğretmenlerin kişilik özellikleri ile iş tatminleri arasındaki ilişkinin incelenmesi. Yeditepe Üniversitesi Sosyal Bilimler Enstitüsü, Yayımlanmamış Yüksek Lisans Tezi.

[34] Ostroff, C. (1992). The relationship between satisfaction, attitudes, and performance: An organizational analysis. Journal of Applied Psychology, 77, 963-974.

[35] Özoğlu, M. (2010). Türkiye'de Öğretmen Yetiştirme Sisteminin Sorunları. Seta Analiz, Say1: 17.

[36] Öztürk, A., \& Deniz, M. (2008). Okul Öncesi Öğretmenlerinin 
Duygusal Zekâ Yetenekleri İş Doyumları ve Tükenmişlik Düzeylerinin Bazı Değişkenler Açısından İncelenmesi. Ilkogretim Online, 7(3).

[37] Özyürek, A. (2009). Okul öncesi eğitimi öğretmen ve yöneticilerinin iş doyumu, kişisel özellik ve mesleki değerlendirilmesi. Milli Eğitim Dergisi, 182, 8-21.

[38] Pedersen, S., \& Liu, M. (2003). Teachers' beliefs about issues in the implementation of a student-centered learning environment. Educational Technology Research and Development, 51(2), 57-76.

[39] Ruble, L. A., Usher, E. L., \& McGrew, J. H. (2011). Preliminary investigation of the sources of self-efficacy among teachers of students with autism. Focus on Autism and Other Developmental Disabilities, 26(2), 67-74.

[40] Schumacker, R. E., \& Lomax, R. G. (1996). A beginner's guide to structural equation modeling. Hillsdale, NJ: Erlbaum.

[41] Shann, M. H. (1998). Professional commitment and satisfaction among teachers in urban middle schools. The Journal of Educational Research, 92(2), 67-73.

[42] Shen, J., Leslie, J. M., Spybrook, J. K., \& Ma, X. (2012). Are principal background and school processes related to teacher job satisfaction? A multilevel study using schools and staffing survey 2003-04. American Educational Research Journal, 49(2), 200-230

[43] Skaalvik, E. M., \& Skaalvik, S. (2009). Does school context matter? Relations with teacher burnout and job satisfaction. Teaching and teacher education, 25(3), 518-524.

[44] Skaalvik, E. M., \& Skaalvik, S. (2014). Teacher self-efficacy and perceived autonomy: Relations with teacher engagement, job satisfaction, and emotional exhaustion. Psychological reports, 114(1), 68-77.

[45] Şişman, M. (2009). Öğretmen Yeterlilikleri: Modern Bir Söylem ve Retorik. İnönü Üniversitesi, Eğitim Fakültesi Dergisi. 10(3), 63-82

[46] Şişman, M. (2016). Türk eğitim sistemi ve okul yönetimi. Pegem Akademi.

[47] Tasdan, M., \& Tiryaki, E. (2008). Comparison of the level of job satisfaction between at private and state primary school teachers. Egitim ve Bilim, 33(147), 54.

[48] Taylor, D. L., \& Tashakkori, A. (1995). Decision participation and school climate as predictors of job satisfaction and teachers' sense of efficacy. The Journal of experimental education, 63(3), 217-230.

[49] Tschannen-Moran, M., \& Hoy, A. W. (2001). Teacher efficacy: Capturing an elusive construct. Teaching and teacher education, 17(7), 783-805.
[50] Tschannen-Moran, M., Hoy, A. W., \& Hoy, W. K. (1998). Teacher efficacy: Its meaning and measure. Review of educational research, 68(2), 202-248.

[51] Tüm Üniversite Listesi. (n.d.). Retrieved April 7, 2017, from http://yok.gov.tr/web/guest/universitelerimiz)

[52] Türkiye ve dünyada öğretmenlik. (n.d.). Retrieved April 7, 2017 , from http://www.egitimbirsen.org.tr/manset-haberleri/\%E2\%80\% 9Cturkiye-ve-dunyada-ogretmenlik $\% \mathrm{E} 2 \% 80 \% 9 \mathrm{D}$-raporumu zu-acikladik/1739/

[53] Türkiye'de öğrenci sayısı (2016, March 18). Retrieved April 6, 2017, from http://www.meb.gov.tr/ogrenci-sayisi-17-milyon-588-bine-y ukseldi/haber/10675/tr

[54] Viel-Ruma, K., Houchins, D., Jolivette, K., \& Benson, G. (2010). The relationships among collective efficacy, teacher self-efficacy, and job satisfaction. Teacher Education and Special Education: The Journal of the Teacher Education Division of the Council for Exceptional Children.

[55] Windschitl, M. (2002). Framing constructivism in practice as the negotiation of dilemmas: An analysis of the conceptual, pedagogical, cultural, and political challenges facing teachers. Review of educational research, 72(2), 131-175.

[56] Yalçın, S., Tavşancıl, E. (2014). Türk Öğrencilerin PISA Başarı Düzeylerinin Veri Zarflama Analizi ile Yıllara Göre Karşılaştırılması. Kuram ve Uygulamada Eğitim Bilimleri 14(3), 947-968.

[57] Yıldırım, İ., \& Vural, Ö. F. (2014). Türkiye'de öğretmen yetistirme ve pedagojik formasyon sorunu. Journal of Teacher Education and Educators, 3(1), 73-90.

[58] Yılmaz, A., \& Ceylan, Ç. B. (2011). İlköğretim okul yöneticilerinin liderlik davranıș düzeyleri ile öğretmenlerin iș doyumu ilişkisi. Kuram ve Uygulamada Egitim Yönetimi Dergisi, 17(2), 277-394.

[59] You, S., Kim, A. Y., \& Lim, S. A. (2015). Job Satisfaction Among Secondary Teachers in Korea Effects of Teachers' Sense of Efficacy and School Culture. Educational Management Administration \& Leadership, 1741143215587311.

[60] Yükseköğretim Programları ve Kontenjanları. (n.d.). Retrieved April 6, 2017 from http://dokuman.osym.gov.tr/pdfdokuman/2015/OSYS/2015OSYSKONTKILAVUZU01072015.pdf

[61] Zee, M. (2016). From general to student-specific teacher self-efficacy. $\mathrm{PhD}$ thesis, Research Institute of Child Development and Education (RICDE), Faculty of Social and Behavioural Sciences (FMG). Retrieved December 20, 2016 from https://pure.uva.nl/ws/files/2792946/173149 02 2 2 .pdf 